\title{
Water Physico-Chemical Characteristics of the Lakes Burera and Ruhondo, Rwanda
}

\author{
Valens Habimana ${ }^{1}$ and Antoine Nsabimana ${ }^{2 *}$ \\ ${ }^{1}$ Department of Chemistry, School of Science, College of Science and Technology, University of Rwanda; \\ 2*Department of Biology, School of Science, College of Science and Technology, University of Rwanda; Po.Box \\ 3900 Kigali, Rwanda. Tel: 0788435561
}

*Corresponding Author: Antoine Nsabimana, antoine.nsabimana@gmail.com

\begin{abstract}
Rwanda possesses multiple lakes, whose properties were rarely described. The present study assessed physico-chemical characteristics of water in Burera and Ruhondo lakes located in highly populated area with steep slopes, which are under extensive agriculture, thus water quality monitoring is important. Both lakes were alkaline with high content of $\mathrm{Mg}$, while Ruhondo had higher electrical conductivity than Burera. Phosphorus and nitrogen exceeded Class III EPA standards indicating that both lakes are at risk of eutrophication.
\end{abstract}

Keywords: water quality, lakes Burera and Ruhondo, Rwanda

\section{INTRODUCTION}

Burera and Ruhondo lakes in Northern Rwanda are of volcanic origin and possess fish resources important for the surrounding population. Besides, both lakes provide water for two hydro-power plants, Mukungwa and Ntaruka, generating around $90 \%$ of the total electricity in Rwanda (Uhorakeye and Möller, 2018). However, little information is available on water quality in these lakes. Earlier studies reported about water pollution in other Rwandan lakes: high level of nutrients and heavy metals in lake Muhazi, rivers Akagera and Nyabarongo (Mupenzi et al., 2009; Usanzineza et al., 2011); pesticide residues in Lake Kivu and other Rwandan lakes (Houbraken et al., 2017).

Assessment of physico-chemical characteristics of a water body is the prime consideration for to assess the quality of water for its best utilization (Angagao et al., 2017). A regular monitoring of water quality is important for water resource management. Surface water quality is suspectible to deteriorate due to various anthropogenic activities (Masresha et al., 2011). This study assessed physico-chemical characteristics of surface water from the lakes Burera and Ruhondo. 


\section{MATERIAL AND METHODS}

Lake Burera is located at $1^{\circ} 26^{\prime} 56.4^{\prime \prime S}$ latitude and $29^{\circ} 46^{\prime} 12^{\prime \prime}$ E longitude, and Lake Ruhondo at $1^{\circ} 29^{\prime} 13.2^{\prime \prime} \mathrm{S}$ latitude and $29^{\circ} 44^{\prime} 52.8^{\prime \prime E}$ longitude (Fig. 1). Lakes Burera and Ruhondo have area of 51.8 and $26.6 \mathrm{Km}^{2}$ (Isumbisho et al., 2011) and maximum depths of 179 and $68 \mathrm{~m}$, respectively. Annual rainfall range is between 1400 and $1800 \mathrm{~mm} /$ year, and temperature between $10^{\circ} \mathrm{C}$ and $25^{\circ} \mathrm{C}$ (Musaninkindi, 2013). Surface water from both lakes was collected monthly from January to April 2019 from three sampling stations. Collected samples of $500 \mathrm{ml}$ each were bottled and transported to the laboratory the same day. The $\mathrm{pH}$, Dissolved Oxygen (DO), Total Dissolved Solids (TDS) and Electrical Conductivity (EC) were recorded in situ using HACH 440d Multimeter. Calcium, Sodium and Potassium ions were determined using flame photometer. Magnesium and Total Alkalinity were determined using titration with Metrohm automatic Titrator. Magnesium was determined from the total hardness minus the pre-determined value of Calcium. The determination of total hardness was by titrating water samples with standardized EDTA using Eriochrome Black T indicator, which forms a stable wine-red complex with magnesium ion. This titration is carried out at a $\mathrm{pH}$ of 10 in $\mathrm{NH}_{3} / \mathrm{NH}_{4}{ }^{+}$buffer.

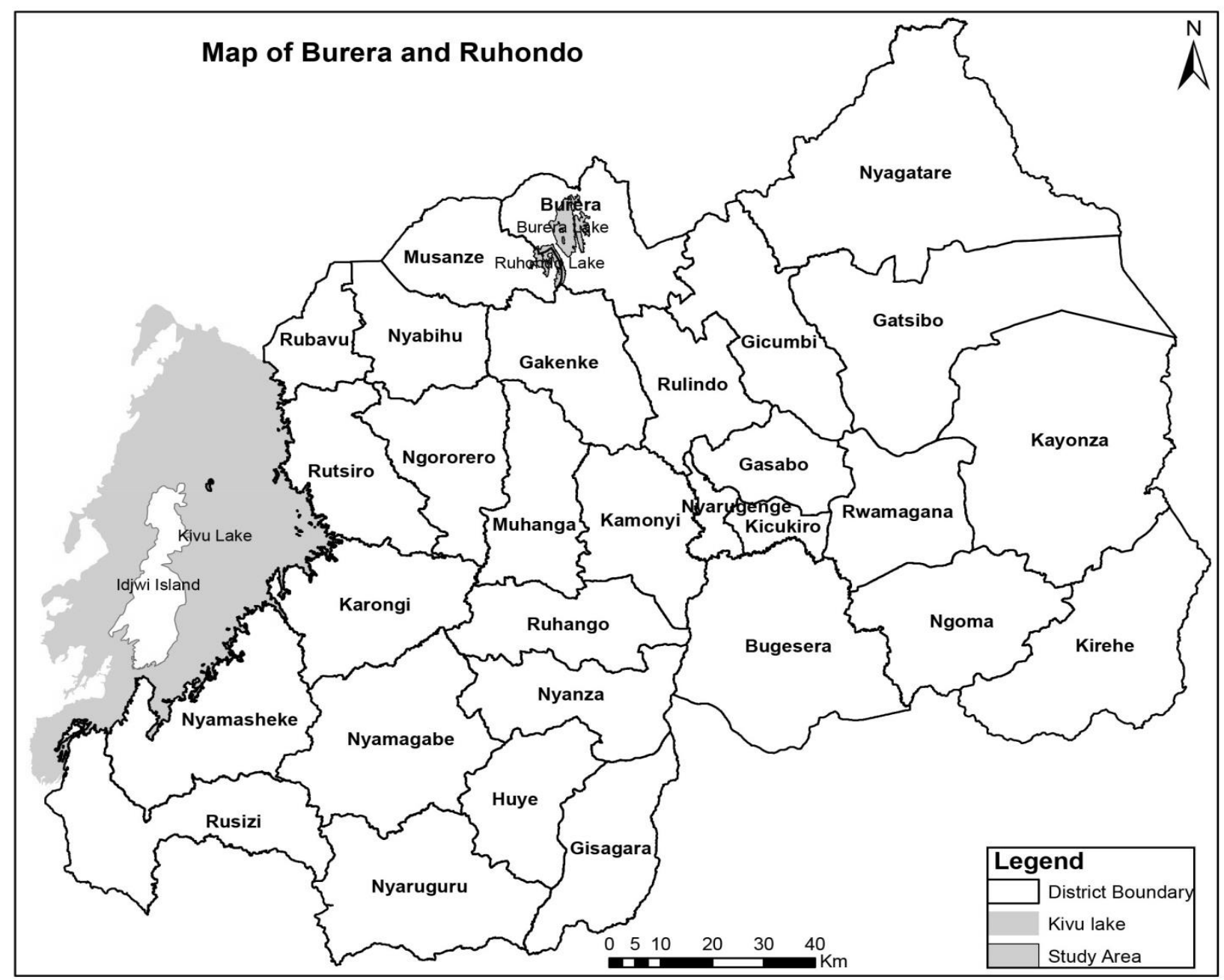

Rwanda Journal of Engineering, Science, Technology and Environment, Volume 3, Issue 2, 2020 


\section{Figure 1: Location of lakes Burera and Ruhondo on Rwanda map}

Organic matter was determined by mixing the samples with potassium dichromate in sulfuric acid in the presence of silver sulfate as oxidation catalyst for straight chain hydrocarbons and mercuric sulfate as complexion agent for halides. The samples were then digested for two hours on a block digester at $150^{\circ} \mathrm{C}$ and analyzed using SHIMADZU UV-Vis-NIR Spectrophotometer. Nitrogenous and phosphorus forms in water were measured using SHIMADZU UV-Vis-NIR Spectrophotometer. For determination of phosphorus, ammonium molybdate and antimony potassium tartrate react with orthophosphates in acid medium for form antimony-phosphomolypdate complex, which is reduced by ascorbic acid to form a blue color complex. The absorbance of standards and the sample are measured with UV-visible spectrophotometer at 650 $\mathrm{nm}$ and the concentration of phosphorus in the sample is determined from the standard curve. Organic phosphorus compounds were converted to orthophosphate by per-sulfate digestion and polyphosphates are converted to the orthophosphates by sulfuric acid hydrolysis so that they can be analyzed. Samples for determination of dissolved forms of phosphorus were filtered before the analysis. Nitrate was estimated using phenol disulfonic acid method, Total Nitrogen was calculated as the sum of Nitrate and Nitrogen determined using Kjeldahl method. Analysis of variance (ANOVA) under General Linear Model was performed using MINIAB 17 to compare water characteristics in both lakes and their dynamic during the period of long rains (from January to April). Prior to ANOVA, variables deviating from normal distribution were checked for outliers and square root or $\log (\mathrm{x}+1)$ transformed.

\section{RESULTS}

Both lakes were alkaline, but Ruhondo had significantly $(\mathrm{p}<0.001)$ higher alkalinity and $\mathrm{pH}$ than Burera with values of 87.2 and $165.2 \mathrm{mg} / \mathrm{l}$ for alkalinity and 7.88 and 8.36 for $\mathrm{pH}$, respectively (Table 1). Organic matter and calcium did not differ in water between both lakes (Table 1). 
Table 1. Mean surface water characteristics of Burera and Ruhondo lakes, Rwanda (Jan.-Apr. 2019)

\begin{tabular}{|c|c|c|c|c|c|c|c|c|c|c|}
\hline $\begin{array}{l}\text { Parameters } \\
\text { Units }\end{array}$ & $\begin{array}{l}\text { Alkalinit } \\
\mathrm{y}, \mathrm{mg} / \mathrm{l} \\
\mathrm{CaCO}_{3}\end{array}$ & $\mathrm{pH}$ & $\begin{array}{l}\mathrm{Ca}, \\
\mathrm{mg} / \mathrm{l}\end{array}$ & $\begin{array}{l}\mathrm{Mg} \\
\mathrm{mg} / \mathrm{l}\end{array}$ & $\begin{array}{l}\mathrm{Na}, \\
\mathrm{mg} / \mathrm{l}\end{array}$ & $\begin{array}{c}\mathrm{K}, \\
\mathrm{mg} / \mathrm{l}\end{array}$ & $\begin{array}{c}\text { Electrical } \\
\text { Conductivity } \\
\mu \mathrm{s} / \mathrm{cm}\end{array}$ & $\begin{array}{l}\text { Total Dissolved } \\
\text { Solids, mg/l }\end{array}$ & $\begin{array}{c}\text { Dissolved } \\
\text { oxygen, } \\
\text { mg/l }\end{array}$ & $\begin{array}{c}\text { Organic } \\
\text { matter, mg/l }\end{array}$ \\
\hline Burera & 87.2 & 7.88 & 12.8 & 30.6 & 17.9 & 13.2 & 113.2 & 57.3 & 7.53 & 2.68 \\
\hline Ruhondo & 165.2 & 8.36 & 11.1 & 74.3 & 32.1 & 32.2 & 221.3 & 116.6 & 7.77 & 2.74 \\
\hline$P$ & $<0.001$ & $<0.001$ & $N S$ & $<0.001$ & $<0.001$ & $<0.001$ & $<0.001$ & $<0.001$ & 0.01 & $N S$ \\
\hline \multirow{3}{*}{$\begin{array}{l}\text { USEPA max acceptable } \\
\text { concentration limit, } \mathrm{mg} / \mathrm{l}\end{array}$} & $50-120$ & $6.5-8.5$ & $N A$ & $N A$ & $N A$ & $N A$ & 700 & 350 & 11 & $N A$ \\
\hline & \multirow{2}{*}{$\begin{array}{l}\text { Nitrogen- } \\
\text { nitrate, } \\
\mathrm{mg} / \mathrm{l}\end{array}$} & \multirow[t]{2}{*}{$\begin{array}{c}\text { Total } \mathrm{N}, \\
\mathrm{mg} / \mathrm{l}\end{array}$} & \multirow[t]{2}{*}{$\begin{array}{l}\text { Total } \mathrm{P}, \\
\mathrm{mg} / \mathrm{l}\end{array}$} & \multirow[t]{2}{*}{ TN:TP } & \multicolumn{2}{|c|}{ Orthophosphates, mg/l } & \multicolumn{2}{|c|}{ Organic $\mathrm{P}, \mathrm{mg} / \mathrm{l}$} & $\begin{array}{c}\text { Condensed } \\
\mathrm{P}, \mathrm{mg} / \mathrm{l}\end{array}$ & $\begin{array}{c}\text { Hydrolysable } \\
\text { P, mg/l }\end{array}$ \\
\hline & & & & & Total & Dissolved & Total & Dissolved & Total & Insoluble \\
\hline Burera & 0.48 & 8.28 & 0.177 & 46.59 & 0.0293 & 0.0285 & 0.1317 & 0.0018 & 0.167 & 0.0052 \\
\hline Ruhondo & 0.42 & 8.38 & 0.184 & 45.56 & 0.0268 & 0.0252 & 0.1437 & 0.0062 & 0.136 & 0.0032 \\
\hline$P$ & $N S$ & $N S$ & $N S$ & $N S$ & 0.001 & $<0.001$ & $N S$ & $<0.001$ & $<0.001$ & $<0.01$ \\
\hline US EPA limit, $m g / l$ & 10 & 0.67 & 0.06 & 22 & $N R$ & $N R$ & $N R$ & $N R$ & $N R$ & $N R$ \\
\hline
\end{tabular}

US EPA limit - maximum permissible concetration limit for US EPA surface waters; NR - Not regulated.

Table 2. Water quality characteristics means from two lakes (Burera and Ruhondo, Rwanda) from January to April 2019

\begin{tabular}{|c|c|c|c|c|c|c|c|c|c|c|c|c|c|c|c|}
\hline & $\begin{array}{c}\text { Alkalinity, } \\
\mathrm{mg} / \mathrm{l} \\
\mathrm{CaCO}_{3}\end{array}$ & $\mathrm{pH}$ & $\begin{array}{c}\mathrm{Ca}, \\
\mathrm{mg} / \mathrm{l}\end{array}$ & $\begin{array}{l}\mathrm{Mg}, \\
\mathrm{mg} / \mathrm{l}\end{array}$ & $\mathrm{Na}, \mathrm{mg} / \mathrm{l}$ & $\begin{array}{c}\mathrm{K}, \\
\mathrm{mg} / \mathrm{l}\end{array}$ & $\begin{array}{c}\text { Electrical } \\
\text { conductivity, } \\
\mu \mathrm{s} / \mathrm{cm}\end{array}$ & $\begin{array}{c}\text { Total } \\
\text { dissolved } \\
\text { solids, } \mathrm{mg} / \mathrm{l}\end{array}$ & $\begin{array}{c}\text { Dissolved } \\
\text { oxygen, } \\
\text { mg/l }\end{array}$ & $\begin{array}{c}\text { Organic } \\
\text { matter, } \\
\mathrm{mg} / \mathrm{l}\end{array}$ & $\begin{array}{l}\text { Nitrogen- } \\
\text { nitrate, } \\
\text { mg/l }\end{array}$ & $\begin{array}{c}\text { Total } \mathrm{N}, \\
\mathrm{mg} / \mathrm{l}\end{array}$ & $\begin{array}{c}\text { Total P, } \\
\mathrm{mg} / \mathrm{l}\end{array}$ & $\begin{array}{c}\text { Total } \\
\text { organic } \\
\mathrm{P}, \mathrm{mg} / \mathrm{l} \\
\end{array}$ & $\begin{array}{c}\text { Total } \\
\text { dissolved } \\
\mathrm{P}, \mathrm{mg} / \mathrm{l}\end{array}$ \\
\hline January & 119.8 & 7.75 & 10.0 & 45.97 & 22.11 & 17.88 & 134.1 & 65.8 & 7.7 & 2.37 & 0.424 & 7.86 & 0.181 & 0.139 & 0.139 \\
\hline February & 116.0 & 7.87 & 10.9 & 47.58 & 22.59 & 18.56 & 131.0 & 63.02 & 7.65 & 2.38 & 0.423 & 8.26 & 0.179 & 0.136 & 0.136 \\
\hline March & 123.7 & 8.26 & 12.0 & 52.95 & 25.04 & 23.67 & 158.0 & 81.12 & 7.58 & 2.70 & 0.475 & 8.62 & 0.185 & 0.142 & 0.142 \\
\hline April & 145.5 & 8.60 & 14.76 & 63.10 & 30.4 & 30.12 & 246.0 & 138.0 & 7.66 & 3.27 & 0.474 & 8.68 & 0.178 & 0.134 & 0.134 \\
\hline$P$ & $<0.01$ & $<0.01$ & 0.05 & $<0.01$ & 0.001 & 0.001 & $<0.001$ & $<0.001$ & $N S$ & 0.001 & $<0.01$ & $<0.05$ & $N S$ & $N S$ & $N S$ \\
\hline
\end{tabular}

NS- not significant at $\mathrm{P}<0.05$. 
Magnesium had the highest concentrations in both lakes (Table 1) reflecting its abundance in underlying basalt from volcanic deposits (Bhateria and Jain, 2016). Ruhondo samples contained almost double values of $\mathrm{Mg}, \mathrm{Na}, \mathrm{K}$, electrical conductivity and total dissolved solids as compared to Burera samples (Table 1). Higher Magnesium, Sodium and Potassium in Lake Ruhondo than in Lake Burera would be the main cause of the difference in electrical conductivity between Ruhondo and Burera. Dissolved oxygen was significantly higher in Ruhondo samples (Table 1). Nitrogen nitrate, total N, total and organic P, and total $\mathrm{N}$ to total $\mathrm{P}$ ratio did not differ between the two lakes (Table 1). Orthophosphates (total and dissolved), condensed and hydrolysable P were higher $(\mathrm{p}<0.01$ or $\mathrm{p}<0.001)$ in Burera than Ruhondo (Table $1)$, but dissolved organic $P$ was higher $(\mathrm{p}<0.01)$ in Ruhondo (Table 1). Among the parameters exceeded EPA maximum permissible limits (USEPA, 2018) were: mean alkalinity in Ruhondo (slightly higher), total $\mathrm{N}$ (exceeded 12 times), total $\mathrm{P}$ (exceeded three times), and N:P ratio (two times) (Table 1). For the period from January to April, there was a trend of significant ( $p<0.05$ or less) increase in alkalinity, $\mathrm{pH}, \mathrm{Ca}, \mathrm{Mg}, \mathrm{Na}, \mathrm{K}$, electrical conductivity, total dissolved solids, organic matter, nitrogen nitrate and total nitrogen (Table 2). However, dissolved oxygen, total $\mathrm{P}$, total organic and dissolved P did not change significantly with wet season (Table 2).

\section{DISCUSSION}

Lakes have more complex and fragile ecosystem as they do not have a self-cleaning ability and therefore readily accumulate pollutants (Watson et al., 2016). The pollutants accumulate along food chains and finally threat human health, or water in the lake may become of inadequate quality and unusable for drinking. One of the environmental threats to African lakes is the high level of nutrients from various sources (Mavuti et al., 1996). Algae feed on those nutrients and grow faster, dying of algae bloom produces high amount of organic matter in water bodies (Liu et al., 2019). Microorganisms use high amount of oxygen in the decomposition of organic matter, a process, which reduces dissolved oxygen in water and results in bad odor production. Low oxygen in water bodies results in stress or even death of while aquatic organism or some species, e.g. fishes used for consumption (Chaudhry and Malik, 2017).

Alkalinity is important parameter of water quality as it indicates the acid neutralizing power of the lake. Based on United States Environmental Protection Agency (USEPA) classification of lakes based on alkalinity, lakes Burera and Ruhondo could be classified as non-sensitive lakes. In acid non-sensitive lakes, the $\mathrm{pH}$ of the lakes is stable as they have the ability to neutralize acid pollution.

Phosphorus in aquatic systems may come from external sources or internally by sediment resuspension. Among different $\mathrm{P}$ compounds, the main was organic $\mathrm{P}$. Cattle and human feces and runoff from surrounding steep slopes may be the sources of organic phosphorus (Leytem et al., 2013). High level of organic phosphorus in lakes Burera and Ruhondo indicates that the lakes 
receive significant quantity of sewage from animal or human waste. Organic phosphorus is also an indication of a possible increase in the phytoplankton in water bodies. The possible source of dissolved organic phosphorus is the discharge of waste water in the lakes (Qin et al., 2015).

Physico-chemical quality of water body is one of the determinants of the types and quantity of aquatic organisms living in. Biochemical reactions, metabolism and immune system of aquatic organisms are affected by the quality of water, in which they live (Paturej et al., 2017). Thus, the change in water quality has negative impact on lakes ecosystem components.

High levels of Nitrogen and Phosphorus witness about important water pollution. Increase in these nutrients accelerates the proliferation of algal blooms and eutrophication, which is a slow natural process but anthropogenic activities have accelerated this process with excess nutrient discharged in water bodies (Liu et al., 2017) It is also possible that the examined lakes receive high amount of waste water due to the high density of population around lakes.

Among the human activities contributing to change in water quality include nutrients coming from agricultural activities, urbanization around the water bodies and rapid increase in population using water bodies as dumping sites. In addition to the mentioned causes of the water quality changes, climate change is another factor accelerating the change in water quality (Bondarenko et al., 2019). Like in other parts of the world, pollution from human activities is also a threat to water bodies in Rwanda, especially lakes (Mukanyandwi et al., 2018).

\section{CONCLUSION}

Our finding revealed high concentrations of $\mathrm{Ca}, \mathrm{Mg}, \mathrm{Na}, \mathrm{N}$ and $\mathrm{P}$, which increased during the long rains period (January - April). Consistent presence of $\mathrm{N}$ and $\mathrm{P}$ contamination irrespective of month is witnessing important levels of water pollution, which may originate from mineral fertilizers, human and animal waste. Increased $\mathrm{N}$ and $\mathrm{P}$ in water could accelerate increased algae growth and thus, lead to rapid eutrophication of the lakes. The findings of this paper inform scientific audience and policy makers about the need to enforce protection measures for both lakes and introduce water quality monitoring.

\section{Acknowledgements}

The authors are grateful to the University of Rwanda, College of Science and Technology, Chemistry Department for providing the laboratory materials and equipment's for sampling and analysis of samples. 


\section{References}

Angagao NB, Quiao MLD, Roa EC, Prado GI (2017) Water quality assessment of the SouthEastern part of Lake Lanao, Philippines. International Letters of Natural Sciences 63: 3441.

Bhateria R, Jain D (2016) Water quality assessment of lake water: a review. Sustainable Water Resources Management 2(2): 161-173.

Bondarenko NA, Ozersky T, Obolkina LA, Tikhonova IV, Sorokovikova EG, Sakirko MV, Potapov SA, Blinov VV, Zhdanov AA, Belykh OI (2019) Recent changes in the spring microplankton of Lake Baikal, Russia. Limnologica 75: 19-29.

Chaudhry FN, Malik MF (2017) Factors affecting water pollution: a review.Journal of Ecosystems and Ecography 7(1): 225.

Houbraken M, Habimana V, Senaeve D, López-Dávila E, Spanoghe P (2017) Multi-residue determination and ecological risk assessment of pesticides in the lakes of Rwanda. Science of the Total Environment 576: 888-894.

Isumbisho M, Petit P, Gashagaza JB, Moreau J (2011) The feeding habit of the Cyprinidae Rastrineobola argentea in its new habitat, lakes Bulera and Ruhondo, two Rwandan lakes (Eastern Africa). Knowledge and Management of Aquatic Ecosystems 403: 04.

Leytem AB, Sims JT, Coale FJ (2004) Determination of phosphorus source coefficients for organic phosphorus sources. Journal of Environmental Quality 33(1): 380-388.

Liu WW, Zhao E, Kuo YM, Jang CS (2017) Identifying the relationships between trophic states and their driving factors in the Shihmen Reservoir, Taiwan. Limnologica 64: 38-45.

Liu S, Feng W, Song F, Li T, Guo W, Wang B, Wang H, Wu F (2019) Photodegradation of algae and macrophyte-derived dissolved organic matter: A multi-method assessment of DOM transformation. Limnologica 77, 125683.

Masresha AE, Skipperud L, Rosseland BO, Zinabu GM, Meland S, Teien HC, Salbu B (2011) Speciation of selected trace elements in three Ethiopian Rift Valley Lakes (Koka, Ziway, and Awassa) and their major inflows. Science of the Total Environment 409(19): 39553970.

Mavuti K, Moreau J, Munyandorero J, Plisnier PD (1996) Analysis of trophic relationships in two shallow equatorial lakes Lake Naivasha (Kenya) and Lake Ihema (Rwanda) using a multispecifies trophic model. Hydrobiologia 321(2): 89-100. 
Mukanyandwi V, Nahayo L, Hakorimana E, Gasirabo A, Otgon S (2018) Review on water resources management and key threats in Rwanda, East Africa. Journal of Water Security 4: 1-8.

Mupenzi, JDLP, Ge J, Habiyaremye G (2009) Major Elements in Lake Muhazi, Rwanda, East Africa. Acta Geologica Sinica-English Edition 83(5): 927-931.

Musaninkindi N (2013) Effect of Cattle Manure, Mineral Fertilizer and Rhizobium Inoculation on Climbing Beans Production and Soil Properties in Burera District, Rwanda. MSc thesis, Kenyatta University Kenya. 65p.

Paturej E, Gutkowska A, Koszałka J, Bowszys M (2017) Effect of physicochemical parameters on zooplankton in the brackish, coastal Vistula Lagoon. Oceanologia 59(1): 49-56.

Qin C, Liu H, Liu L, Smith S, Sedlak DL, Gu AZ (2015) Bioavailability and characterization of dissolved organic nitrogen and dissolved organic phosphorus in wastewater effluents. Science of the Total Environment 511: 47-53.

Uhorakeye T, Möller B (2018) Assessment of a climate-resilient and low-carbon power supply scenario for Rwanda. International Journal of Sustainable Energy, Planning and Management 17: 45-60.

Usanzineza D, Nhapi I, Wali UG, Kashaigili JJ, Banadda N (2011) Nutrients inflow and levels in lakes: a case study of Lake Muhazi, Rwanda. International Journal of Ecology and Development 19(S11): 53-62.

USEPA (2018) Water Quality Standards. US Environmental Protection Agency, 2018.

Watson SB, Miller C, Arhonditsis G, Boyer GL, Carmichael W, Charlton MN, Confesor, R, Depew DC, Höök TO, Ludsin SA, Matisoff G (2016) The re-eutrophication of Lake Erie: Harmful algal blooms and hypoxia. Harmful algae 56: 44-66. 